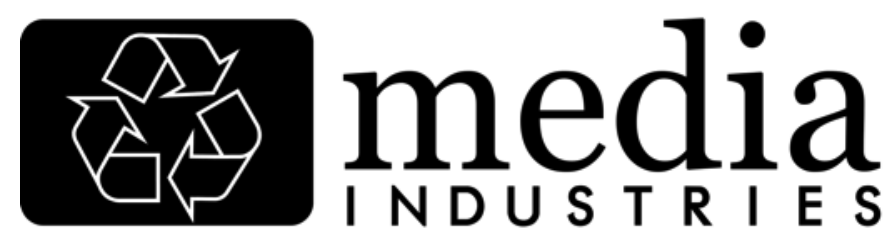

\title{
The Discourse on Media Is Dominated by Reactionary Cant
}

\author{
Toby Miller ${ }^{1}$ \\ Cardiff University, Murdoch University \\ tobym69 [AT] icloud.com
}

\begin{abstract}
:
This brief note examines two interrelated themes that I think need to be at the core of studying the media industries. Neither will be popular, because they are critical and they veer away from the norms of US graduate schooling and Englishlanguage journals. The first is that we need to focus on cultural labor. The second is that we need to focus on the environment, specifically the media's destructive impact on the world's ecology over centuries. These critiques sometimes help encourage workers to organize and corporations to reform, but they have yet to gain major currency in academia outside environmental science. A decent future for the cognitariat and the earth depends on the centrality of these topics to each course, publication, policy, and initiative undertaken by and about the media. Business as usual needs to be shaken up.
\end{abstract}

Keywords: Cultural Labor, Environment, E-waste

The dominant discourse on the media industries in the United States and across the angloparlante world is profoundly conservative. Reactionary rhetoric characterizes much popular discussion, college teaching, bourgeois journalism, public policy, third-sector activism, and research-whether coin-operated or academic (to the extent that the two can be distinguished).

The discourse takes one or several of the following tacks:

- Because of new technologies and practices of consumption, concentration of media ownership and control no longer matters-information is finally free, thanks to multipoint distribution and destabilized hierarchies.

- Consumers are sovereign and can transcend class and other categories.

- Young people are liberated from media control.

- Journalism is dying as everyone and their owl become sources of both news and reporting.

- Creative destruction is an accurate and desirable description of economic innovation. 
- When scholars observe media workers and audiences, they discover that ideology critique is inappropriate.

- Marxist political economy denies the power of audiences and users and the irrelevance of boundaries - it is pessimistic and hidebound.

- Cultural imperialism critiques miss the creativity and resilience of national and subnational forms of life against industrial products.

- Media effects studies are inconsequential-audiences outwit corporate plans and psyfunction norms.

What is left out of these seemingly dynamic and innovative but in fact tired and venerable lines?

- the ecological impact of the media

- questions of labor and life in the cognitariat

- those who essentially live outside consumption, beyond multinational marketswithout an electricity grid and potable water, for example

- citizenship rights and responsibilities

- concentrated ownership and obedient regulation

- the critique of cultural imperialism that resonates with populations and activists

- the fact that the fantasy of media organizations being vulnerable to the power of the young, consumers being rebellious, and new technology laying waste to all is as old as those organizations themselves

- the expansion of newspapers outside the Global North-people still line up in Barranquilla by the dozen each morning to place classified advertisements in the local paper, for instance

- the real use of new technologies - for example, people citing one another's sexting or Fand T-word activity in family courts to undermine claims to parental responsibility, leading to judgments that deny people custody of their children

A key to the reactionary nature of media studies is its devotion to its object of study, and especially its ahistorical celebration of technology. George Orwell dissected the antecedents of this cybertarian rhetoric seventy years ago. His critique resonates today:

Reading recently a batch of rather shallowly optimistic "progressive" books, I was struck by the automatic way in which people go on repeating certain phrases which were fashionable before 1914. Two great favorites are "the abolition of distance" and "the disappearance of frontiers." I do not know how often I have met with the statements that "the aeroplane and the radio have abolished distance" and "all parts of the world are now interdependent."2

Sound familiar? Of course it does. Technological determinists' lack of originality and tendency to repeat exploded myths as if they were new and true refuse to lie down and die. No wonder Facebook claims its social media site can "decrease world conflict" through inter-cultural communication, and Twitter modestly announces itself as "a triumph of humanity." 3 This is yet one more cliché dalliance with new technology's supposedly innate capacity to endow users with transcendence, but no less powerful for its banality because of the interests it serves and the cult of newness it subscribes to. 4

Equally romantically, but with a franker commitment to capital accumulation, bourgeois economists argue that cell phones have streamlined hitherto inefficient markets in remote areas 
of the Global South, enriching people in zones where banking services and commercial information are scarce due to distance and terrain. Exaggerated claims for the magic of mobile telephony in places that lack electricity, plumbing, fresh water, hospital care, and the like include "the complete elimination of waste" and massive reductions of poverty and corruption through the empowerment of individuals. ${ }^{5}$

Cell phones and the like are said to obliterate geography, sovereignty, and hierarchy, replacing them with truth and beauty. This deregulated, individuated, technologized world makes consumers into producers, frees the disabled from confinement, encourages new subjectivities, rewards intellect and competitiveness, links people across cultures, and allows billions of flowers to bloom in a postpolitical cornucopia. People fish, film, fornicate, and finance from morning to midnight, from Marx to Godard (minus the struggle). Consumption is privileged, and labor and the environment are forgotten. How very jolly.

Time magazine exemplified the utopic silliness of these tendencies in its choice of "You" as 2006 "Person of the Year," declaring, "You control the Information Age. Welcome to your world."6 The Guardian is prey to the same touching magic: someone called "You" heads its current list of the hundred most important folks in the media. ${ }^{7}$ Sweet, isn't it?

The discourse incarnates reader, audience, consumer, and player autonomy - the neoliberal intellectual's wet dream of music, movies, television, and everything else converging under the sign of omniscient, omnipotent, omnipresent populism. The dream invests, with unparalleled gusto, in Schumpeterian entrepreneurs, evolutionary economics, and creative industries. Its true believers have never seen an app they didn't like, or a socialist idea they did. Faith in devolved media-making amounts to a secular religion, offering transcendence in the here and now via a "literature of the eighth day, the day after Genesis." 8 Machinery, not politicaleconomic activity, is the guiding light.

\section{Labor}

In cybertarian fantasies of this new era, readers become writers, listeners transform into speakers, viewers emerge as stars, fans are academics, and vice versa, while the economy glides into an ever greener postindustrialism. The comparatively cheap and easy access to making and circulating meaning afforded by internet media and genres is thought to have eroded the oneway hold on culture that saw a small segment of the world as producers and the larger segment as consumers, even as it makes for a cleaner economy. New technologies supposedly allow us all to become simultaneously cultural consumers and producers (prosumers) - no more factory conditions, no more factory emissions.

Zine writers are screenwriters. Bloggers are copywriters. Children are columnists. Bus riders are journalists. And think of the job prospects that follow! Coca-Cola hires African Americans to drive through the inner city selling soda and playing hip-hop. AT\&T pays San Francisco buskers to mention the company in their songs. Urban performance poets rhyme about Nissan cars for cash, simultaneously hawking, entertaining, and researching. Subway's sandwich commercials are marketed as made by teenagers. Cultural studies majors become designers. Graduate students in New York and Los Angeles read scripts for producers then pronounce on whether they tap into audience interests. Precariously employed part-timers spy on fellow spectators in theaters to see how they respond to coming attractions. Opportunities to vote in the Eurovision Song Contest or a reality program disclose the profiles and practices of viewers, who can be monitored and wooed in the future. Online end-user licensing agreements for 
corporate video games ensure that players sign over their cultural moves and perspectives to the very companies they are paying in order to participate. ${ }^{9}$

In other words, corporations are using discounted labor. Business leeches want flexibility in the people they employ, the technologies they use, the places where they do business, and the amounts they pay - and inflexibility of ownership and control. The neoclassical doxa preached by neoliberal chorines favors an economy where competition and opportunity cost are in the litany and dissent is unforgiveable, thought to be as crazed as collective industrial organization. In short, "decent and meaningful work opportunities are reducing at a phenomenal pace in the sense that, for a high proportion of low- and middle-skilled workers, full-time, lifelong employment is unlikely."10 Even the US National Governors Association recognizes the reality: "routine tasks that once characterized middle class work have either been eliminated by technological change or are now conducted by low-wage but highly skilled workers." 11 The way that cultural workers, from jazz musicians to street artists, have long labored without regular compensation and security now models the expectations we are all supposed to have, rather than our parents' or grandparents' assumptions about lifelong, or at least steady, employment.

Hence the success of Mindworks Global Media, a company outside New Delhi that provides Indian-based journalists and copyeditors who work long distance for newspapers whose reporters are supposedly in the United States and Europe. There are 35-40 percent cost savings. ${ }^{12}$ Or consider the advertising agency Poptent, which undercuts big competitors in sales to major clients by exploiting prosumers' labor in the name of "empowerment." That empowerment takes the following form: Poptent pays the creators of homemade commercials US $\$ 7,500$, it receives a management fee of US\$40,000, and the buyer saves about US $\$ 300,000$ off the usual price. ${ }^{13}$

How might we account for this phenomenon? Antonio Negri redeployed the concept of the cognitariat from the Reaganite futurist Alvin Toffler. ${ }^{14}$ Negri defines the cognitariat as people undertaking casualized cultural work who have heady educational backgrounds yet live at the uncertain interstices of capital, qualifications, and government in a post-Fordist era of mass unemployment, limited-term work, and occupational insecurity. They are sometimes complicit with these circumstances because their identities are shrouded in autotelic modes of being: work is pleasure and vice versa; labor becomes its own reward.

The reality is that the media largely remain controlled by communications conglomerates, which frequently seek to impose artist-like conditions on their workforces (the cable versus broadcast TV labor process is a notorious instance). In other words, the cognitariat-interns, volunteers, contestants, and so on-may create "cool stuff," but the primary beneficiaries of their innovations are corporations. ${ }^{15}$ This aspect is largely missing from media studies.

In film schools, for example, work is addressed as its own reward, with unpaid internships a prize route to a selfless life to come. In other words, labor is self-sacrifice, a quasi-religious commitment to transcendence where money is grubby and volunteering or activism a higher path. Alternatively, film schools can be seen as assembly lines of masculine privilege. Thirty years ago, Michelle Citron and Ellen Seiter explained that women were marginalized in production classes and victimized in production texts. ${ }^{16}$ Seiter recently revisited that work. ${ }^{17}$ She found nothing had changed in terms of male film students' taste for having aggression toward women be the touchstone of their art. The University Film and Video Association's 2010 conference dedicated special sessions to the tendency for US film school students from across 
the world to emphasize brutal violence directed at women in their work. ${ }^{18}$ When I was at the Tisch School of the Arts, I served on a committee charged with stopping male directors from cutting female actors' bodies in the name of attaining authentic performances from them.

And quite apart from the misogyny, many film school grads are of course in wonderfully satisfying jobs working for YouTube's 100 new channels, the fruit of Google's US $\$ 100$ million production (and US\$200 million marketing) bet that five-minute online shows will kill off TV. Explosions are routinely filmed for these channels near my old loft in downtown Los Angeles. The workers blowing things up are paid US\$15 an hour. ${ }^{19}$ Other film school graduates find employment with talent agencies, doing useful things like associating B-list celebrities with social causes in order to raise their profiles: find a major issue such as a new environmental problem or geopolitical hot spot, pitch it to your guy, set up a foundation, and await admiring press coverage. Luxury, really. But they've all got smartphones ...

\section{Environment}

The cell phone may be the ur-object of the contemporary cognitariat. What are some of its impacts other than providing a means of connecting postindustrial workers to job "opportunities?" When old and obsolete cell phones, like other media technologies, are junked, they become electronic waste (e-waste), the fastest-growing component of municipal cleanups around the Global North. E-waste generates serious threats to worker health and safety wherever plastics and wires are burnt, monitors smashed and dismantled, and circuit boards grilled or leached with acid, while the toxic chemicals and heavy metals that flow from such practices have perilous implications for local and downstream water, soil, and residents. Much electronic salvage and recycling is undertaken in the Global South by preteen girls, who work with discarded television sets and computers as well as cognitariat phone castoffs to find precious metals and dump the remains in landfills. The e-waste ends up there after export and import by "recyclers" who eschew landfills and labor in the Global North in order to avoid the cost and regulation of recycling in countries that prohibit such destruction to environment and workers. Businesses forbidden to dump in local landfills merrily mail it elsewhere. ${ }^{20}$

There are always contradictions within utopias, of course. I visited London's Design Museum in August 2013. It had a terrific exhibit that used the notion of an ecological backpack to illustrate the minerals and labor that go into our cell phones. I took a wee photo: 


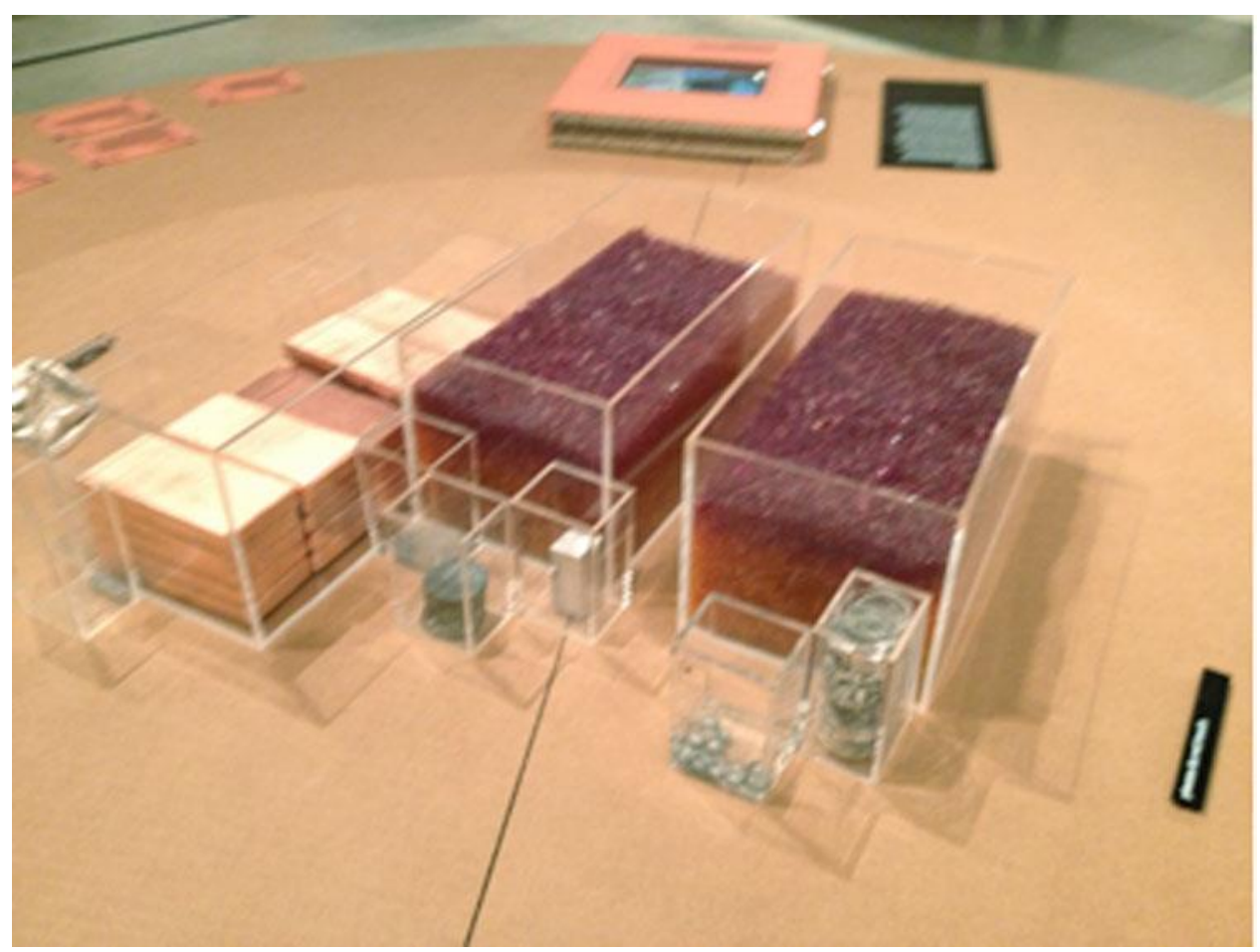

But alongside this excellent work drawing attention to the appalling environmental impact of mobile telephony (though nothing was said of millions killed, enslaved, and raped in the struggle over the conflict minerals that enable these gadgets) the Museum was celebrating what it immodestly called "A New Industrial Revolution." This extraordinary marvel was allegedly already "Here." I'll conclude this rant against cant by engaging the new wonder. Cognitarians, stand by for the latest wonder.

The exciting new arrival in question is three-dimensional printing-sometimes known as "additive manufacturing." 3-D offers "mass customization" - in other words, taking generic commercial designs and matching them to customers' needs through computer-aided design and manufacture. This promises to alter factory assembly, alter the global division of labor, and alter the printing industry.

Now customers are able not only to adjust specifications for home appliances, art works, or apparel online but also to actually make them. Hospitals, for instance, are tailoring hip replacements to patients' individual characteristics and dentists cater to particular gums and teeth. The customization relies on 3-D printers, which transform digital files into material objects by printing slices of molten plastic or powder. Their purchase price can be as low as US\$650.21

But there are negative sides to this development. The US government has already reacted with concern in the face of the ability to "print" weapons using the technology: the notorious "Liberator" or "Wiki Weapon." 22 Read all about it at the website of Defense Distributed, a group that sees itself as the inheritor of free-speech traditions dating from John Milton. Before these heroes of cybertarianism were ordered to take the site down, one hundred thousand people had downloaded its deadly instructions. Of course, the idea is already under fuller development at the Pentagon, which can hardly wait to deliver customized weaponry to soldiers in the field. ${ }^{23}$ In addition to American First and Second Amendment questions and the 
threat of violence, 3-D printers also raise anxieties about counterfeit and contraband products and consumer safety. ${ }^{24}$

But what concerns me most here is a potentially serious environmental issue, with implications for occupational and amateur health and safety. For while some analysts predict that 3-D printers will have positive environmental effects because they will reduce the amount of carbon used to transport goods over large distances, ${ }^{25}$ recent research suggests the need for caution. ${ }^{26}$

Many desktop 3-D printers use heated thermoplastic extrusion and deposition. Numerous factory studies have associated such processes with dangerous aerosol emissions, but little research has been done into the new printers - and they generally lack exhaust ventilation or filtration systems. The first such investigation focuses on particle emissions, specifically ultrafine particle (UFP) concentrations, within an office using 3-D printing. The UFP emissions were alarmingly sizable. Why alarming? The trouble is that UFPs are very efficient at depositing themselves in our lungs, airways, and brains, and they may produce high concentrations of other absorbed and condensed compounds. What are the results of such exposure? The epidemiological record associates UFP concentrations with cardiorespiratory mortality, strokes, and asthma. ${ }^{27}$

So what should our attitude be as analysts of the media industries? The precautionary principle places the burden of proof onto proponents of industrial processes to show that they are environmentally safe. The idea is to prevent harm rather than clean up messes after the fact, with potentially fatal consequences for life-so it is about prevention rather than cure. ${ }^{28}$ The doctrine is opposed to the more common cost-benefit analysis, which looks at the pluses and minuses of consumer satisfaction versus safety. ${ }^{29}$ That should be a motif and guide for all our work.

Back at the Design Museum, it was quite shocking to see workers and visitors interacting directly with 3-D printers in the absence of any obvious warnings. Instead, this was a grand new cornucopia on display, with all the fun of the fair.

Celebratory endorsements as per "The Future Is Here" have become generic advertisements for an industry that may deliver far more than new kinds of efficiency and customization. And that delivery could be very toxic indeed. The partial job done by the museum in covering the horrors of cell phones is inadequate. Its appalling embrace of new toxic technologies compromises that achievement. The exhibit shows the impact of cybertarianism as the latest technological determinism - reinvented with retreads each time it is rolled out; seemingly new, but relying on the built-in obsolescence of gadgets and theories that imbue historical forgetfulness and fealty to capital. The show urges us to bind together labor and the environment in our analyses and use them to deter our seemingly overwhelming desire to find the beautiful in the new (that is actually ugly and old).

Oh, if you're still a true believer, listen to the Hot Toddies' song "HTML."

1 Toby Miller is 20 percent Professor of Journalism, Media and Cultural Studies at Cardiff University/Prifysgol Caerdydd in Wales and 40 percent Sir Walter Murdoch Professor of Cultural Policy Studies at Murdoch University in Australia. The author and editor of over thirty books, his work has been translated into Spanish, Chinese, Portuguese, Japanese, Turkish, German, and Swedish. His two most recent volumes 
are Greening the Media (with Richard Maxwell) and Blow Up the Humanities (both 2012). He can be contacted at tobym69@icloud.com and his adventures scrutinized at www.tobymiller.org.

2 George Orwell, “As I Please," Tribune, May 12, 1944.

3 “A Cyber-House Divided," Economist, September 4, 2012, 61-62.

${ }^{4}$ Christine L. Ogan, Manaf Bashir, Lindita Camaj, Yunjuan Luo, Brian Gaddie, Rosemary Pennington, Sonia Rana, and Mohammed Salih, "Development Communication: The State of Research in an Era of ICTs and Globalization," Gazette 71, no. 8(2009): 655-70.

${ }^{5}$ Robert Jensen, "The Digital Provide: Information Technology, Market Performance, and Welfare in the South Indian Fisheries Sector," Quarterly Journal of Economics 122, no. 3 (2007): 879-924.

${ }^{6}$ Lev Grossman, “Time's Person of the Year: You," Time, last modified December 13, 2006.

7 “1. You.," Media Guardian 100, Guardian, September 1, 2013.

8 James W. Carey, "Historical Pragmatism and the Internet," New Media E Society 7, no. 4 (2005): 443-55.

9 Toby Miller, "The Shameful Trinity: Game Studies, Empire, and the Cognitariat," in Guns, Grenades, and Grunts: First-Person Shooter Games, ed. Gerald A. Voorhees, Josh Call, and Katie Whitlock (New York: Continuum, 2012), 113-30.

10 Cosma Orsi, "Knowledge-Based Society, Peer Production and the Common Good," Capital $\mathcal{E}$ Class 33 (2009): 31-51.

11 Erin Sparks and Mary Jo Watts, Degrees for What Jobs? Raising Expectations for Universities and Colleges in a Global Economy (Washington, DC: National Governors Association for Best Practices, 2011).

12 Nandini Lakshman, "Copyediting? Ship the Work Out to India," Business Week, July 8, 2008.

13 Ibid.

14 Antonio Negri, Goodbye Mister Socialism (Paris: Seuil, 2007); Alvin Toffler, Previews and Premises (New York: William Morrow, 1983).

15 Toby Miller, “The Cognitariat,” Cognitariat: Journal of Contingent Labor 1 (2013).

${ }^{16}$ Michelle Citron and Ellen Seiter, "The Woman with the Movie Camera," JumpCut: A Review of Contemporary Cinema 26 (1981): 61-62.

17 Ellen Seiter, "On Cable, Tech Gods, and the Hidden Costs of DIY Filmmaking: Thoughts on "The Woman with the Movie Camera," JumpCut: A Review of Contemporary Cinema 53

http://www.ejumpcut.org/currentissue/seiterProdnTeach/index.html.

(2011),

${ }^{18}$ Jennifer Proctor, River E. Branch, and Kyja Kristjansson-Nelson, "Woman with the Movie Camera Redux: Revisiting the Position of Women in the Production Classroom," JumpCut: A Review of Contemporary Cinema 53 (2011).

${ }^{19}$ Sam Thielman, "YouTube Commits \$200 Million in Marketing Support to Channels," AdWeek, May 3, 2012.

${ }^{20}$ Richard Maxwell and Toby Miller, Greening the Media (New York: Oxford University Press, 2012).

21 Shan Li, “3D Printers Are Beginning to Make an Impression," Los Angeles Times, last modified July 27, 2013.

22 Ibid. 
${ }^{23}$ Robert Beckhusen, "In Tomorrow's Wars, Battles Will Be Fought with a 3-D Printer," Wired, last modified May 17, 2013.

24 "Your Future Will Be Manufactured on a 3-D Printer," Bloomberg.com, last modified May 12, 2013.

25 Thomas Campbell, Christopher Williams, Olga Ivanova, and Banning Garrett, Could 3D Printing Change the World? Technologies, Potential, and Implications of Additive Manuacturing, Atlantic Council, 2011.

26 Brent Stephens, Parham Azimi, Zeineb El Orch, and Tiffanie Ramos, "Ultrafine Particle Emissions from Desktop 3D Printers," Atmospheric Environment 79 (2013): 33439.

27 Ibid.

28 Maxwell and Miller, Greening the Media.

29 See, for example, "The Wingspread Consensus Statement on the Precautionary Principle," the Science and Environmental Health Network, January 26, 1998.

\section{Bibliography}

“1. You." Media Guardian 100, The Guardian, September 1, 2013.

“A Cyber-House Divided.” Economist, September 4, 2012.

Beckhusen, Robert. "In Tomorrow's Wars, Battles Will Be Fought with a 3-D Printer." Wired. Last modified May 17, 2013.

Campbell, Thomas, Christopher Williams, Olga Ivanova, and Banning Garrett. Could 3D Printing Change the World? Technologies, Potential, and Implications of Additive Manuacturing. Atlantic Council, 2011. Last modified October 17, 2011.

Carey, James W. “Historical Pragmatism and the Internet." New Media E Society 7, no. 4 (2005): 443-55.

Chmielewski, Dawn C. "Poptent's Amateurs Sell Cheap Commercials to Big Brands." Los Angeles Times, May 8, 2012.

Citron, Michelle, and Ellen Seiter. "The Woman with the Movie Camera." Jump Cut: A Review of Contemporary Media 26 (1981): 61-62.

Grossman, Lev. “Time's Person of the Year: You." Time. Last modified December 13, 2006.

Jensen, Robert. “The Digital Provide: Information Technology, Market Performance, and Welfare in the South Indian Fisheries Sector." Quarterly Journal of Economics 122, no. 3 (2007): 879-924

Lakshman, Nandini. "Copyediting? Ship the Work Out to India." Business Week, July 8, 2008.

Li, Shan. "3D Printers Are Beginning to Make an Impression." Los Angeles Times. Last modified July 27, 2013. Maxwell, Richard, and Toby Miller. Greening the Media. New York: Oxford University Press, 2012. 
Miller, Toby. "The Shameful Trinity: Game Studies, Empire, and the Cognitariat." In Guns, Grenades, and Grunts: First-Person Shooter Games, edited by Gerald A. Voorhees, Josh Call, and Katie Whitlock, 113-30. New York: Continuum, 2012.

Miller, Toby. (2013). “The Cognitariat." Cognitariat: Journal of Contingent Labor 1. Negri, Antonio. Goodbye Mister Socialism. Paris: Seuil, 2007.

Ogan, Christine L., Manaf Bashir, Lindita Camaj, Yunjuan Luo, Brian Gaddie, Rosemary Pennington, Sonia Rana, and Mohammed Salih. "Development Communication: The State of Research in an Era of ICTs and Globalization." Gazette 71, no. 8 (2009): 655-70.

Orsi, Cosma. "Knowledge-Based Society, Peer Production and the Common Good." Capital $\mathcal{E}$ Class 33 (2009): 31-51.

Orwell, George. “As I Please.” Tribune. Last modified May 12, 1944.

Proctor, Jennifer, River E. Branch, and Kyja Kristjansson-Nelson. "Woman with the Movie Camera Redux: Revisiting the Position of Women in the Production Classroom." Jump Cut: A Review of Contemporary Cinema 53 (2011).

Seiter, Ellen. “On Cable, Tech Gods, and the Hidden Costs of DIY Filmmaking: Thoughts on 'The Woman with the Movie Camera.'" Jump Cut: A Review of Contemporary Cinema 53 (2011).

Sparks, Erin, and Mary Jo Watts. Degrees for What Jobs? Raising Expectations for Universities and Colleges in a Global Economy. Washington, DC: National Governors Association Center for Best Practices, 2011.

Stephens, Brent, Parham Azimi, Zeineb El Orch, and Tiffanie Ramos. "Ultrafine Particle Emissions from Desktop 3D Printers." Atmospheric Environment 79 (2013): 334-39.

Thielman, Sam. "YouTube Commits \$200 Million in Marketing Support to Channels." AdWeek, May 3, 2012.

Toffler, Alvin. Previews and Premises. New York: William Morrow, 1983.

“Your Future Will Be Manufactured on a 3-D Printer." Bloomberg.com. Last modified May 12, 2013.

\section{$(\mathrm{Cc})$ BY-NC-ND}

Copyright (C) 2015 (Toby Miller). Media Industries is an open-access, peer-reviewed, online academic journal. As such, we aim to participate in the open exchange of information. This work is licensed under a Creative Commons Attribution Noncommercial No Derivatives (by-nc-nd) License. Under this license, this work is available for sharing and noncommercial distribution provided the appropriate attribution is given. 